\title{
YOUNG RANGER BANDS
}

\author{
By R. C. St. Clair \\ B.C. Forest Service
}

T ALL started in 1931 with a forest fire near Palling, a small community on the C.N.R. Several lads from the locality picked up shovel and axe, made their way with all haste to the spot and had the fire well under control when the Ranger arrived. This action gave the nucleus of an idea to Mr. W. C. Saunders. Large forest fires had been prevalent in that part of the Province for several years, and he, an ardent forest protectionist, reasoned that if the old people would not be careful with fire in the woods, it might be possible to organize the youth of the district, so that the younger generation at least would feel a real responsibility for the protection of the timber resources. And so he proceeded to organize the first "Young Ranger Band" with the help, advice and coroperation of the local forest officers.

A rather clever idea, and one that aided considerably in interesting the youngsters, was to make it a secret society, something after the nature of a lodge, with a ritual, election of officers, installations, initiations, pass words, and a very serious and solemn oath to protect the forest from fire. The fact that the society is a secret one and that the youngsters jealously guard their secrets, excites curiosity on the part of other youngsters with a consequent desire to be elected to membership.

Since the first Young Ranger Band was organized at Palling the movement has spread both east and west along the Canadian National Railway and Bands have been established in many communities from Hazelton to McBride.

Much experience has been gained and in some places ground has been lost, but there is a slow general expansion of the movement. The Ritual, and Rules and Procedure have been standardized and printed. The requirements for the successful establishment of a Young Ranger Band have been found to be:

(a) An adult who will interest himself in the movement, to advise and direct, but not to dictate, the policy of the Band. He should act as the adult leader, contact the parents, and generally promote the Band's interests. Such adult leaders have been found among the ministry, school teachers and business men of the communities. Without such leadership, experience has shown that a Band is almost certain to fail.

(b) A local forest officer who will look upon the work of interesting youngsters in forest protection as part of his regular job; who will attend meetings; help organize socials and picnics; and in general aid and abet the adult leader and the officers of the Band in keeping up interest. There are 
many ways in which the local Ranger can interest the youngsters in the forests, limited of course by local conditions and the time from other work he can spend with them.

Probably the strongest and best organized Young Ranger Band is the one established at Burns Lake, where excellent adult and forest officer leadership has been maintained. A small island in Burns Lake has been reserved by the Provincial Government for the use of the Band. The members have, by their own efforts, cleaned up the underbrush and dead and down timber, built trails and boat landings and have made of this island a minia. ture park. The boys of the Band cut building logs, hauled them to the island over the ice in the winter and with some adult help have built a very fine Lodge building.

Ranger Island, as it is called, is used each summer as the location of a two weeks summer camp for Young Rangers from the several Bands throughout the District, and invited guests. The camp is under the direction of adult leaders, and sports, swimming and hikes, as well as lectures and sing-songs, keep the youngsters busy. A cook's wages and food supplies represent about the only cost.

Now as to results. It is dangerous to draw conclusions from circumstantial and intangible evidence. Many individual cases of youngsters taking initial action on fires have come to the attention of the Forest Service. The relations between the general public along the C.N.R. and officials charged with fire prevention and control have changed from indifference, if not outright antagonism, to wholehearted support, co'operation and help. In the Burns Lake Ranger District there has been no loss of merchantable timber by fire in the last eight years. I cannot help but feel that these young Ranger Bands have had a material influence in these better public relations.

It is well known that the ideas and thoughts given a child in his formative years influence his adult life's philosophy. One of the greatest religious faiths has been built on this tenet. The basic idea behind the Young Ranger Band movement has a similar psychological approach. Many of the early members have now grown to maturity and have taken their places as citizens of the community. The lessons learned in their youth still stay with them and their influence is felt in making the whole community forest fire conscious.

While it may take a generation or two to do it, perhaps by some such scheme of influencing the youth, we may finally build on a solid foundation forest-fire-free communities, so that eventually our man-caused fires will be reduced to the vanishing point, and thereby solve our greatest forestry problem in Canada. 